\title{
Spontaneous Intramuscular Hematoma due to Subcutaneous Enoxaparın
}

\author{
Subkütan Enoksaparine Bağlı Spontan Kas İçi Hematom
}

\author{
(1) Ahmet Gürdal1, (1) Mustafa Kemal Yeniay², (1) Şükrü Çetin¹, (1) Kadriye Kılıçkesmez¹ \\ 1University of Health Sciences, Șișli Hamidiye Etfal Training and Research Hospital, Clinic of Cardiology, İstanbul, Turkey \\ 2University of Health Sciences, Șișli Hamidiye Etfal Training and Research Hospital, Clinic of Internal Medicine, İstanbul, Turkey
}

\begin{abstract}
Low molecular weight heparins (LMWH) are generally used for acute coronary syndrome (ACS) treatment. Although bleeding is the most common complication associated with the use of LMWH, it that can lead to hemodynamic disorder is rare. Here we present a case of rectus abdominis intramuscular hematoma (RAIH) after use of subcutaneous LMWH. A 73 -year-old female patient was hospitalized with a diagnosis of ACS and pneumonia. Due to ACS, LMWH was started as anticoagulant therapy. When follow up in the service, the patient developed sudden abdominal pain. Immediately, abdominal ultrasonography and computed tomography were performed and left RAIH was detected. Emergency surgery was not intended and supportive therapy (fluid, erythrocyte suspension, analgesics) was given to the patient. Hemodynamic parameters of the patient were followed up closely. Hematoma declined in follow up and reducing the patient's symptoms. Coronary angiography was performed when patient stabilizied hemodynamically and stent was placed to obtuse marginal artery which is a branch of the circumflex artery. After the procedure, the patient without symptoms was discharged with the recommendations. Patients who LMWH administered subcutaneously and was performed suddenly abdominal pain with a palpable mass in physical examination, RAIH should be considered in the differential diagnosis. In patients with predisposing factors to reduce the risk of fatal RAIH, lower dose of LMWH should be used and care should be taken to make the injection under the skin. When RAIH develops, early diagnosis and a multidisciplinary approach and not be delayed treatment are the most important factor in combating these complications.
\end{abstract}

Keywords: Acute coronary syndrome, low molecular weight heparins, enoxaparin, hematom

\section{öZ}

Düşük molekül ağılıklı heparinler (DMAH) akut koroner sendrom (AKS) tedavisinde sık kullanılmaktadır. DMAH kullanımına bağlı en sık görülen komplikasyon kanama olmakla birlikte hemodinamik bozukluğa yol açabilecek kanamalar nadiren görülmektedir. Burada subkütan DMAH kullanım sonrası rektus abdominis kas içi hematom (RKIH) gelișen bir olgu sunuldu. Yetmiş üç yaşında kadın hasta AKS ve pnömoni tanısı ile servise yatırıldı. AKS nedeni ile antikoagülan tedavi olarak DMAH bașlandı. Takiplerde ani gelișen karın ağrısı olan hastanın yapılan batın ultrasonografi ve batın bilgisayarlı tomografide sol RKIH saptandı. Acil cerrahi düşünülmeyen hastaya destek tedavisi (eritrosit süspansiyon replasmanı, sIvı ve analjezik tedavi) verildi ve hemodinamik olarak yakın takip edildi. Takiplerde hematom geriledi, hastanın semptomları azaldı. Hemodinamik olarak stabilleșen hastaya yapılan koroner anjiyografi neticesinde sirkümfleks arter obtus marjinal yan dalına stent yerleştirildi. İșlem sonrası semptomu olmayan hasta önerilerle taburcu edildi. Subkütan DMAH uygulanan, ani gelişen karın ağrısı ve fizik muayenede ele gelen kitlesi olan hastalarda RKiH ayırıcı tanıda akla gelmelidir. Ölümle sonuçlanabilen RKIH riskini azaltmak için predispozan faktörü olan hastalarda daha düşük doz DMAH kullanılmalı ve enjeksiyonun deri altına yapılmasına dikkat edilmelidir. RKiH geliștiğinde erken tanı, multidisipliner yaklașım ve tedavinin geciktirilmemesi bu komplikasyon ile mücadeledeki en önemli unsurlardır.

Anahtar Kelimeler: Akut koroner sendrom, düşük molekül ağırlıklı heparin, enoksaparin, hematom
Address for Correspondence/Yazıșma Adresi: Ahmet Gürdal, University of Health Sciences, Șişli Hamidiye Etfal Training and Research Hospital, Clinic of Cardiology, İstanbul, Turkey

Phone: +90 5064781441 E-mail: gurdal27@hotmail.com ORCID ID: orcid.org/0000-0002-2168-4937

Cite this article as/Atıf: Gürdal A, Yeniay MK, Çetin \$,, Kılıçkesmez K. Spontaneous Intramuscular Hematoma due to Subcutaneous Enoxaparın. İstanbul Med J 2019; 20(1): 75-7.
Received/Geliş Tarihi: 27.01.2018 Accepted/Kabul Tarihi: 23.04.2018

(C) Copyright 2019 by the Istanbul Training and Research Hospital/Istanbul Medical Journal published by Galenos Publishing House.

(C) Telif Hakkı 2019 Istanbul Ĕgitim ve Araștırma Hastanesi/Istanbul Tıp Dergisi, Galenos Yayınevi tarafından basılmıștır. 


\section{Introduction}

Heparin is a routine agent used in the treatment of acute coronary syndrome (ACS). Low molecular weight heparin (LMWH) is a type of heparin commonly used in the treatment of ACS due to its ease of use. Although major bleeding complications due to LMWH are frequently observed, bleeding that causes severe hemodynamic impairment is rarely observed. In this article, we present a case of rectus intramuscular hematoma (RIMH) after subcutaneous LMWH use.

\section{Case Report}

A 73-year-old woman without a history of chronic disease was admitted to the emergency department with palpitations and shortness of breath. Her vitals were as follows: blood pressure: 136/84 mmHg, heart rate: 154 / min and arrhythmic, respiratory rate: 20/minute, oxygen saturation: 92\% and body temperature: $37.4{ }^{\circ} \mathrm{C}$. Electrocardiogram (ECG) was consistent with atrial fibrillation rhythm and sinus rhythm was achieved after $25 \mathrm{mg}$ intravenous diltiazem. T wave negativity was seen in lateral leads in sinus rhythm ECG. Auscultation revealed crepitant rales at the base of the right lung. Chest X-ray showed findings in favor of pneumonia in the right lung. The patient's complete blood count (CBC) and biochemistry values were as follows: leukocyte: $19320 / \mu \mathrm{L}(\mathrm{n}=4500$ 10500/ $\mu \mathrm{L})$, hemoglobin: $11.4 \mathrm{~g} / \mathrm{dL}(\mathrm{n}=11.5-15.5 \mathrm{~g} / \mathrm{dL})$, creatinine: $1.15 \mathrm{mg} / \mathrm{dL}$ ( $\mathrm{n}=0-1.17 \mathrm{mg} / \mathrm{dL}$ ), glucose: $222 \mathrm{mg} / \mathrm{dL}(\mathrm{n}=82-115 \mathrm{mg} / \mathrm{dL})$, sodium: $137 \mathrm{mmol} / \mathrm{L}(\mathrm{n}=135-148 \mathrm{mmol} / \mathrm{L})$, potassium: $4.2 \mathrm{mmol} / \mathrm{L}$ $(\mathrm{n}=3.5-5.5 \mathrm{mmol} / \mathrm{L})$, aspartate aminotransferase: $48 \mathrm{U} / \mathrm{L}(\mathrm{n}=0-40 \mathrm{U} / \mathrm{L})$, alanine aminotransferase: $25 \mathrm{U} / \mathrm{L}(\mathrm{n}=0-41 \mathrm{U} / \mathrm{L})$, C-reactive protein: 173.2 $\mathrm{mg} / \mathrm{L}(\mathrm{n}=0-5 \mathrm{mg} / \mathrm{L})$, D-Dimer: $3090 \mathrm{ug} / \mathrm{L}(\mathrm{n}=0-500 \mathrm{ng} / \mathrm{L})$ and troponin I: $1.04 \mathrm{ng} / \mathrm{mL}(\mathrm{n}=0-0.06 \mathrm{ng} / \mathrm{mL})$. The patient was hospitalized in the coronary intensive care unit with the diagnoses of atrial fibrillation, ACS and pneumonia. Anti-ischemic treatment (LMWH, clopidogrel, aspirin, ramipril, nitroglycerin, metoprolol, atorvastatin) was initiated for ACS, and antibiotherapy was started for pneumonia with the suggestion of department of infectious diseases. Coronary angiography was planned following infection control. Echocardiography showed moderate left ventricular systolic function (ejection fraction: 35\%), left ventricular wall motion abnormalities, mild mitral and tricuspid regurgitation. During follow-up, the patient's symptoms decreased and acute phase reactants regressed. On the sixth day of admission, the patient had abdominal pain on the left lower quadrant that increases with movement. Physical examination revealed a palpable mass on the left lower quadrant of the abdomen. In the abdominal ultrasonography of the patient, a $65 \times 30 \mathrm{~mm}$ lesion compatible with hematoma was found on the anterior surface of the left rectus muscle. Supportive treatment (fluid and analgesic treatment) was started. LMWH was discontinued in his treatment; but clopidogrel and aspirin in treatment were continued because of ACS. Serial CBC tests were performed. Emergency surgery was not considered by department of general surgery. Abdominal computed tomography of the patient that was performed one day later revealed a $97 \times 55 \mathrm{~mm}$ hematoma at the left rectus abdominis muscle (Figure 1). On followup, hemoglobin levels decreased to $8.2 \mathrm{~g} / \mathrm{dL}$ and 2 units of erythrocyte suspension were administered to the patient. The hemoglobin level after replacement was $10.4 \mathrm{~g} / \mathrm{dL}$. Coronary angiography was performed to the patient when hemodynamic stabilization was achieved. It revealed $70 \%$ stenosis in the obtuse marginal artery (CX-OM), a branch of the

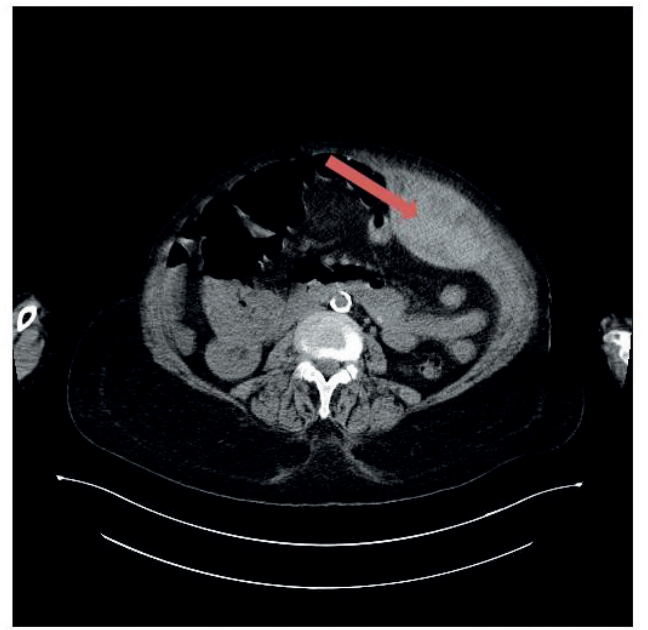

Figure 1. Left rectus abdominis intramuscular hematoma on computed tomography

circumflex artery, and a stent was placed successfully. The patient had no symptoms at the follow-up period and control abdominal ultrasound showed that the diameter of hematoma decreased to $60 \times 32 \mathrm{~mm}$. The patient, who was symptom free and had stable hemoglobin levels, was discharged with recommendations. Written informed consent was obtained from the patient for publication of this case report.

\section{Discussion}

RIMH is an uncommon picture reported on case basis (1). It may cause a misdiagnosis with clinical similarity to acute abdomen and may be fatal if not noticed (2). RIMH can be caused by rupture of the rectus muscle due to strain and rupture of the inferior epigastric artery. The risk increases in elderly, chronic kidney and liver diseases, degenerative muscle diseases, collagen tissue diseases, hematological diseases, and chronic obstructive pulmonary disease (COPD) patients with frequent coughing that leads to increased intra-abdominal pressure $(1,3)$.

The cases of LMWH-related RIMH are generally elderly female patients with COPD who have chronic cough (2). It is more common in women than in men $(4,5)$. In one case series, 11 of 12 patients who received anticoagulant therapy and developed RIMH were female, and 7 had complaints of frequent cough (6). It is reported that its high prevalence in women may be due to deformation of the rectus abdominis muscle due to pregnancy (4). The fact that our patient was old and female and had frequent coughs due to pneumonia may have facilitated the development of RIMH.

LMWH has been widely used in the treatment of ACS, pulmonary thromboembolism and deep vein thrombosis. As it can be administered subcutaneously instead of infusion and follow-up activated partial thromboplastin time is not required, it has replaced unfractionated heparin (7-9). The most common complication of LMWH is associated with bleeding. In a study, enoxaparin-induced major bleeding was found to be $6.5 \%$ and minor bleeding was $18.5 \%$ (10). In another study, 14 major bleeding were observed in 554 patients using enoxaparin and 4 of them were reported as hematoma spreading in the anterior abdominal wall muscles (11). 
It has been reported that intramuscular injection causes hematoma in the development of LMWH-associated RIMH, but that it is not sufficient to develop hematoma alone. It has also been reported that the rupture of inferior epigastric artery due to strain of the rectus abdominis muscle in case of cough that increases intra-abdominal pressure or local anticoagulant effect causes extensive hematoma $(1,12)$. In our case, the presence of frequent cough episodes due to pneumonia may have facilitated the development of RIMH.

One of the most important bleeding complications that may occur due to subcutaneous LMWH is the anterior abdominal wall intramuscular hematoma. This complication can be seen mostly in injections applied to the abdomen. Changing the injection site reduces this complication development but does not completely eliminate it. As a matter of fact, no injection was made in the hematoma area in our patient. Although intramuscular hematomas may be self-limited, surgical intervention may be required in some cases and may cause death in rare cases (13). In our case, the RIMH was self-limited despite aspirin and clopidogrel treatment due to ACS, and the patient's symptoms regressed with supportive therapy (erythrocyte suspension replacement, fluid and analgesic treatment).

\section{Conclusion}

In patients who were administered subcutaneous LMWH and who had a sudden onset abdominal pain and a mass in the physical examination, RIMH should be considered in the differential diagnosis. The frequent use of LMWH in the treatment of ACS in cardiology practice, especially in the treatment of older female patients with predisposing factors, RIMH may be expected to occur more frequently. In patients with predisposing factors, a lower dose of LMWH should be used and the injection should be performed subcutaneously to reduce the risk of fatal RIMH. Early diagnosis, multidisciplinary approach and early initiation of treatment are the most important factors in the management of this complication.

Informed Consent: Written informed consent was obtained from the patient for publication of this case report.

Peer-review: Externally peer-reviewed.

Author Contributions: Concept - A.G., K.K.; Design - A.G., M.K.Y.; Supervision - A.G., K.K.; Data Collection and/or Processing - A.G., M.K.Y., S.Ç.; Analysis and/or Interpretation - S..C., K.K.; Literature Search - M.K.Y., S.C..; Writing Manuscript - A.G.; Critical Review - K.K., S.Ç.
Conflict of Interest: No conflict of interest was declared by the authors.

Financial Disclosure: The authors declared that this study received no financial support.

\section{References}

1. Tsapatsaris NP. Low dose heparin. A cause of hematoma of rectus abdominis. Arch Int Med 1991; 151: 597-9.

2. Dubinsky IL. Hematoma of the rectus abdominis: case report and review of the literature. J Emerg Med 1997;15 2: 165-6.

3. Cullen TS. Lesion of the rectus abdominis muscle situmulating acute intraabdominal condition: hemorrhage into or beneath rectus muscle stimulating acute abdominal condition. Bull John Hopkins Hosp 1937; 61: $317-4$.

4. Brotzman G. Rectus sheath hematoma in an anticoagulated patient. J Fam Prac 1991; 151: 597-9.

5. Fletcher $\mathrm{H}$, Joseph $\mathrm{W}$. Bleeding into the rectus abdominis muscle. Int Surg 1973; 58: 97-9.

6. Berna JD, Zuazu I, Madrigal M, García-Medina V, Fernández C, Guirado F. Conservative treatment of large rectus sheath hematoma in patients undergoing anticoagulant therapy. Abdom Imag 2000; 25: 230-4.

7. The Colombus Investigators. Low molecular weight heparin in the treatment with venous thromboembolism. N Eng J Med 1997; 337: 657-6.

8. Simoneu G, Sors H, Charbonnier B, Page Y, Laaban JP, Azarian R, et al. THESEE study group. A comparison of low molecular weight heparin with unfractionated heparin for pulmonary embolism. N Eng J Med 1997; 337: 663-6.

9. Levine M, Gent M, Hirsh J, Leclerc J, Anderson D, Weitz J, et al. A comparison of low molecular weight heparin administrated primarily at home with unfractionated heparin administrated in the hospital for proximal deep-vein trombosis. N Eng J Med 1996; 334: 677-8.

10. Goodman SG, Cohen M, Bigonzi F, Gurfinkel EP, Radley DR, Le louer V. et al. Randomized trail of low molecular weight heparin (enoxaparin) versus unfractioned heparin for unstable coronary artery disease: one year results of ESSSENCE study. J Am Coll Cardiol 2000; 36: 693-6.

11. Martin H. Ellis, Ruth H, Noa T, Shirley S, Kovlenko I, Kozmiakova M, et al. Hemorrhagic complications in patients treated with anticougulant doses of a low molecular weight heparin (enoxaparin) in routine hospital practice. Clin Appl Thromb Hemost 2006: 12; 199-2.

12. Webb KB, Hadzima S. Hematoma of the rectus abdominis muscle: a complication of subcutaneous heparin therapy. South Med J 1987; 80: 911-2.

13. Akdeniz B, Türker S, Aslan Ö, Güneri S. Düșük molekül ağırlıklı heparin kullanılması sonrası gelişen abdominal rektus kılıf hematomu: üç olgu sunumu ve literatürün gözden geçirilmesi. Türk Kardiyoloji Derneği 2002; 30; 313-3. 